\title{
PENGGUNAAN METODE PSEUDOSPEKTRAL PADA APROKSIMASI TURUNAN FUNGSI PERIODIK
}

\author{
MUHAMMAD FIRMAN PEBRIZAL, MAHDHIVAN SYAFWAN \\ Program Studi Matematika, \\ Fakultas Matematika dan Ilmu Pengetahuan Alam, Universitas Andalas, \\ Kampus UNAND Limau Manis Padang, Indonesia, \\ ftm.pebrizal@gmail.com
}

\begin{abstract}
Abstrak. Metode pseudospektral merupakan metode alternatif selain metode beda hingga untuk mengaproksimasi turunan suatu fungsi. Pada makalah ini akan dijelaskan penurunan metode pseudospektral pada fungsi periodik. Matriks diferensiasi pada metode ini dibangun dari invers transformasi Fourier diskrit dari data diskrit fungsi periodik yang akan dicari turunannya. Metode pseudospektral ini kemudian dibandingkan dengan metode beda hingga melalui simulasi numerik pada suatu fungsi periodik. Hasil simulasi yang diperoleh menunjukkan bahwa metode pseudospektral menghasilkan galat yang jauh lebih kecil dibandingkan dengan metode beda hingga, meskipun hanya menggunakan sejumlah kecil titik diskritisasi.
\end{abstract}

Kata Kunci: Metode beda hingga, fungsi periodik, transformasi Fourier diskrit, matriks diferensiasi, interpolan band-limited

\section{Pendahuluan}

Metode beda hingga (finite difference method) merupakan salah satu metode konvensional yang sering dipakai dalam mengaproksimasi turunan di suatu titik fungsi. Penurunan rumus metode beda hingga diperoleh dengan menggunakan ekspansi deret Taylor yang melibatkan titik-titik partisi. Galat yang dihasilkan dari metode ini dapat dibuat sekecil mungkin sesuai keinginan. Dalam pengkonstruksiannya, semakin banyak titik partisi yang digunakan mengakibatkan galat yang dihasilkan semakin kecil. Hanya saja pada penggunaan aplikasi dalam menghitung hampiran dengan menggunakan metode ini melibatkan data berupa penggunaan titik partisi dalam jumlah yang besar, sehingga beban komputasi akan semakin berat.

Dalam makalah ini akan dibahas mengenai metode alternatif yang dapat digunakan dalam mengaproksimasi turunan fungsi sehingga galat yang dihasilkan dan beban komputasi yang diperoleh semakin kecil. Sebagian besar pembahasan pada makalah ini merujuk pada [2].

\section{Metode Beda Hingga}

Pandang fungsi $v(t)$ untuk $a \leq t \leq b$. Fungsi tersebut akan dicari hampiran turunannya dengan menggunakan metode beda hingga. Misalkan domain $t \in[a, b]$ dipartisi sebanyak $N+1$ titik partisi dengan lebar masing-masing selang partisinya 
adalah $h=(b-a) / N$. Titik-titik partisinya dapat ditulis sebagai berikut:

$$
t_{j}=a+j h, \quad j=0,1, \ldots, N .
$$

Dalam hal ini $t_{0}=a$ dan $t_{N}=b$. Selanjutnya nilai fungsi $v(t)$ di setiap titik partisi $t_{j}$ ditulis

$$
v_{j}=v\left(t_{j}\right), \quad j=0,1, \ldots, N .
$$

Perlu diperhatikan bahwa penggunaan metode beda hingga yang dipakai dalam membandingkan dengan metode pseudospektral adalah metode beda hingga orde4. Berikut teorema mengenai metode beda hingga orde- 4 .

Teorema 2.1. [1] (Rumus Beda Pusat dengan Orde $\mathcal{O}\left(h^{4}\right)$ ) Misalkan $v \in$ $C^{5}[a, b]$ dan $t-2 h, t-h, t, t+h, t+2 h \in[a, b]$. Maka

$$
v^{\prime}(t) \approx \frac{-v(t+2 h)+8 v(t+h)-8 v(t-h)+v(t-2 h)}{12 h} .
$$

Lebih lanjut, terdapat $c \in[a, b]$ sedemikian sehingga

$$
v^{\prime}(t)=\frac{-v(t+2 h)+8 v(t+h)-8 v(t-h)+v(t-2 h)}{12 h}+E(v, h),
$$

dimana

$$
E(v, h)=-\frac{h^{4} v^{(5)}(c)}{30}=\mathcal{O}\left(h^{4}\right) .
$$

Dalam notasi partisi, persamaan (2.1) dapat ditulis dengan

$$
v_{j}^{\prime} \approx \frac{-v_{j+2}+8 v_{j+1}-8 v_{j-1}+v_{j-2}}{12 h} .
$$

Misalkan fungsi yang ingin diturunkan adalah fungsi periodik dengan periode $T_{p}=b-a$. Dalam hal ini berlaku

$$
v_{0}=v_{N} \quad \text { dan } \quad v_{1}=v_{N+1} .
$$

Selanjutnya tulis

$$
\mathbf{v}=\left[v_{1}, v_{2}, \ldots, v_{N}\right]^{T} \quad \text { dan } \quad \mathbf{v}^{\prime}=\left[v_{1}^{\prime}, v_{2}^{\prime}, \ldots, v_{N}^{\prime}\right]^{T} .
$$

Dalam hal ini $v_{0}$ tidak dilibatkan karena $v_{0}=v_{N}$.

Dengan demikian rumus beda pusat (2.3) dapat direpresentasikan dalam bentuk matriks sebagai berikut:

$$
\mathbf{v}^{\prime}=D \mathbf{v}
$$

dimana

$$
D=\frac{1}{h}\left[\begin{array}{cccccccc}
0 & \frac{2}{3} & -\frac{1}{12} & & & \frac{1}{12} & -\frac{2}{3} \\
-\frac{2}{3} & 0 & \frac{2}{3} & -\frac{1}{12} & & & \frac{1}{2} \\
& \ddots & \ddots & \ddots & \ddots & \ddots & \\
& & & & & & \\
-\frac{1}{12} & & & \frac{1}{12} & -\frac{2}{3} & 0 & \frac{2}{3} \\
\frac{2}{3} & -\frac{1}{12} & & & \frac{1}{12} & -\frac{2}{3} & 0
\end{array}\right] .
$$


60 Muhammad Firman Pebrizal, Mahdhivan Syafwan

\section{Konstruksi Metode Pseudospektral pada Fungsi Periodik}

\subsection{Transformasi Fourier Diskrit}

Pandang suatu fungsi periodik $v(t)$ dengan periode $2 \pi$ pada domain $[0,2 \pi]$. Misalkan jumlah titik partisi domain tersebut adalah $N$ (genap), yaitu $t_{j}=j h$ dengan $j=1,2, \ldots, N$ dan $h=2 \pi / N$. Beberapa catatan yang harus diperhatikan adalah sebagai berikut:

(1) Titik $t_{0}=0$ tidak dilibatkan karena fungsi $v$ periodik, yaitu $v\left(t_{0}\right)=v\left(t_{N}\right)$.

(2) Translasi ke suatu interval lain, seperti $[-\pi, \pi]$, tidak akan menghasilkan perbedaan sama sekali dalam hasil yang akan diperoleh.

(3) Fungsi dengan periode selain $2 \pi$ diselesaikan dengan mengalikan faktor skala yang sesuai.

(4) Perhitungan untuk $N$ ganjil dilakukan serupa dengan $N$ genap, namun terdapat beberapa perbedaan dalam formula yang dihasilkan.

Selanjutnya, transformasi Fourier diskrit dari v dapat didefinisikan dengan

$$
\hat{v}_{k}=h \sum_{j=1}^{N} e^{-i k t_{j}} v_{j}, \quad k=-\frac{N}{2}+1, \ldots, \frac{N}{2},
$$

sedangkan invers transformasi Fourier diskritnya diberikan oleh

$$
v_{j}=\frac{1}{2 \pi} \sum_{k=-N / 2+1}^{N / 2} e^{i k t_{j}} \hat{v}_{k}, \quad j=1, \ldots, N .
$$

Karena bilangan gelombang tertinggi pada (3.2) muncul secara asimetris, maka dengan mendefinisikan $\hat{v}_{-N / 2}=\hat{v}_{N / 2}$, persamaan (3.2) dapat dimodifikasi menjadi

$$
v_{j}=\frac{1}{2 \pi}\left(\frac{1}{2} e^{i(-N / 2) t_{j}} \hat{v}_{-N / 2}+\sum_{k=-N / 2+1}^{N / 2-1} e^{i k t_{j}} \hat{v}_{k}+\frac{1}{2} e^{i(N / 2) t_{j}} \hat{v}_{N / 2}\right),
$$

untuk $j=1, \ldots, N$.

\subsection{Interpolan Band-Limited}

Definisikan fungsi

$$
p(t)=\frac{1}{2 \pi}\left(\frac{1}{2} e^{i(-N / 2) t} \hat{v}_{-N / 2}+\sum_{k=-N / 2+1}^{N / 2-1} e^{i k t} \hat{v}_{k}+\frac{1}{2} e^{i(N / 2) t} \hat{v}_{N / 2}\right)
$$

untuk $t=[0,2 \pi]$. Perhatikan bahwa $p(t)$ menginterpolasi $\mathbf{v}$, yaitu $p\left(t_{j}\right)=v_{j}$ untuk $j=1,2, \cdots, N$. Lebih lanjut, transformasi Fourier dari $p$ adalah

$$
\hat{p}(k)= \begin{cases}\hat{v}_{k} & k \in\left\{-\frac{N}{2}+1,-\frac{N}{2}+2, \ldots, \frac{N}{2}\right\} \\ 0 & \text { lainnya. }\end{cases}
$$


Fungsi $\hat{p}$ disebut fungsi band-limited dan $p(t)$ disebut interpolan band-limited dari $\mathbf{v}(k)$. Selanjutnya, tulis

$$
v_{j}=\sum_{m=1}^{N} v_{m} \delta_{j-m}
$$

dimana $\delta_{j}$ adalah fungsi delta Kronecker diskrit periodik, yang didefinisikan sebagai

$$
\delta_{j}=\left\{\begin{array}{l}
1, j \equiv 0(\bmod N) \\
0, j \neq 0(\bmod N) .
\end{array}\right.
$$

Transformasi Fourier diskrit dari $\delta_{j}$ adalah

$$
\hat{\delta}_{k}=h .
$$

Interpolan band-limited dari $\delta_{j}$ adalah

$$
q(t)= \begin{cases}\frac{h}{2 \pi} \cos (t / 2) \frac{\sin (N t / 2)}{\sin (t / 2)}, & t \neq 0 \\ 1, & t=0\end{cases}
$$

Karena $N / 2=\pi / h$, maka persamaan (3.5) menjadi

$$
S_{N}(t) \equiv q(t)= \begin{cases}\frac{\sin (\pi t / h)}{(2 \pi / h) \tan (t / 2)}, & t \neq 0, \\ 1, & t=0,\end{cases}
$$

yang dikenal sebagai fungsi sinc periodik.

Selanjutnya interpolan band-limited dari $\mathbf{v}$ adalah

$$
\begin{aligned}
p(t) & =\frac{1}{2 \pi}\left(\frac{1}{2} e^{i(-N / 2) t} \hat{v}_{-N / 2}+\sum_{k=-N / 2+1}^{N / 2-1} e^{i k t} \hat{v}_{k}+\frac{1}{2} e^{i(N / 2) t} \hat{v}_{N / 2}\right) \\
& = \begin{cases}\sum_{m=1}^{N} v_{m} \frac{\sin \left(N\left(t-t_{m}\right) / 2\right)}{(2 \pi / h) \tan \left(\left(t-t_{m}\right) / 2\right)}, t \neq t_{m}, \\
\sum_{m=1}^{N} v_{m} .1,\end{cases} \\
& =\sum_{m=1}^{N} v_{m} S_{N}\left(t-t_{m}\right) .
\end{aligned}
$$

\subsection{Matriks Diferensiasi}

Karena $v_{j}=p\left(t_{j}\right)$, maka

$$
v_{j}^{\prime}=p^{\prime}\left(t_{j}\right)=\left.\sum_{m=1}^{N} v_{m} S_{N}^{\prime}\left(t-t_{m}\right)\right|_{t=t_{j}} .
$$

Dalam bentuk matriks, ekspresi sebelumnya dapat ditulis $\mathbf{v}^{\prime}=D \mathbf{v}$, dimana entri matriks $D$ diberikan oleh

$$
d_{j m}=\left.S_{N}^{\prime}\left(t-t_{m}\right)\right|_{t=t_{j}}, \quad j, m=1,2, \ldots, N .
$$

Entri pada kolom ke- $N$ adalah

$$
d_{j N}=S_{N}^{\prime}\left(t_{j}-t_{N}\right)=\left\{\begin{array}{lr}
0, & j \equiv 0 \bmod N \\
\frac{d}{d t}\left[\frac{\sin \left(\pi\left(t-t_{N}\right) / h\right)}{(2 \pi / h) \tan \left(\left(t-t_{N}\right) / 2\right)}\right]_{t=t_{j}=j h}, & j \neq \equiv \bmod N .
\end{array}\right.
$$


Karena $t_{N}=2 \pi$, maka $S^{\prime}\left(t_{j}-t_{N}\right)=S^{\prime}\left(t_{j}\right)$, sehingga

$$
d_{j N}=S_{N}^{\prime}\left(t_{j}\right)= \begin{cases}0 & j \equiv 0 \bmod N \\ \frac{1}{2}(-1)^{j} \cot (j h / 2), & j \neq 00 \bmod N .\end{cases}
$$

Adapun entri-entri pada kolom-kolom yang lain diperoleh dengan cara 'menggeser' entri-entri pada kolom ke- $N$ sedemikian sehingga membentuk matriks Toeplitz. Secara umum, matriks diferensiasi dari metode pseudospektral untuk fungsi periodik$2 \pi$, dengan menggunakan lebar selang $h$ dan $N$ titik, diberikan oleh

$$
D=\left[\begin{array}{ccccc}
0 & & & -\frac{1}{2} \cot \left(\frac{1 h}{2}\right) \\
-\frac{1}{2} \cot \left(\frac{1 h}{2}\right) & \ddots & & \ddots & \frac{1}{2} \cot \left(\frac{2 h}{2}\right) \\
\frac{1}{2} \cot \left(\frac{2 h}{2}\right) & & \ddots & & -\frac{1}{2} \cot \left(\frac{3 h}{2}\right) \\
-\frac{1}{2} \cot \left(\frac{3 h}{2}\right) & & & \ddots & \vdots \\
\vdots & & \ddots & \ddots & \frac{1}{2} \cot \left(\frac{(N-1) h}{2}\right) \\
\frac{1}{2} \cot \left(\frac{(N-1) h}{2}\right) & & & & 0
\end{array}\right] .
$$

\section{Simulasi Numerik}

Sebagai contoh ilustrasi, fungsi yang akan dicari turunannya adalah

$$
u(t)=e^{\sin (t)} \cos (t), \quad \text { untuk } t \in[-\pi, \pi] .
$$

Turunan eksak fungsi $u(t)$ adalah

$$
u^{\prime}(t)=e^{\sin (t)} \cos ^{2}(t)-e^{\sin (t)} \sin (t) .
$$

Berikut hasil plot grafik turunan fungsi dari tiap-tiap metode dan plot galat yang dihasilkan 
Dari simulasi numerik yang dilakukan, dapat disimpulkan bahwa metode pseudospektral mempunyai keunggulan dibandingkan dengan metode beda hingga. Pada metode pseudospektral, galat dari aproksimasi turunan fungsi yang diperoleh jauh lebih kecil dibandingkan dengan metode beda hingga, padahal jumlah titik partisi yang digunakan jauh lebih sedikit.

\section{Kesimpulan}

Langkah awal dalam pengkonstruksian matriks diferensiasi yang nantinya digunakan dalam menghitung aproksimasi nilai suatu fungsi pada metode pseudospektral adalah dengan mengubah fungsi tersebut dalam bentuk diskrit. Selanjutnya dicari transformasi Fourier diskrit beserta invers transformasi Fourier diskrit dari fungsi tersebut. Langkah berikutnya adalah dengan mendefinisikan suatu fungsi yang menginterpolasi invers transformasi Fourier diskrit dari fungsi yang akan dicari turunannya (disebut fungsi interpolan band-limited). Interpolan band-limited ini kemudian dimanipulasi secara aljabar melalui penggunaan fungsi delta Knocker diskrit periodik. Selanjutnya, hasil akhir dari fungsi interpolan band-limited tersebut dicari turunannya sehingga diperoleh matriks diferensiasi untuk turunan fungsi periodik.

Dari simulasi numerik yang dilakukan, dapat disimpulkan bahwa metode pseudospektral mempunyai keunggulan dibandingkan dengan metode beda hingga. Pada metode pseudospektral, galat dari aproksimasi turunan fungsi yang diperoleh jauh lebih kecil dibandingkan dengan metode beda hingga, padahal jumlah titik partisi yang digunakan jauh lebih sedikit.

Untuk penelitian selanjutnya, penulis menyarankan hal-hal berikut:

(1) Penjelasan mengenai konstruksi metode pseudospektral dapat dikembangkan untuk kasus fungsi yang lebih umum.

(2) Perlu dilakukan analisis galat dari metode pseudospektral ini, sehingga perbandingan keakuratannya dengan metode beda hingga atau metode lainnya dapat dijelaskan secara matematis.

\section{Daftar Pustaka}

[1] Mathews, John H., K.D. Fink. 1992. Numerical Methods for Computer Science, Engineering, and Mathematics. Edisi ke-2. Prentice-Hall, Englewood Cliffs.

[2] Trefethen, Llyod N. 2000. Spectral Methods in Mathlab. SIAM: Society for Industrial and Applied Mathematics. Philadelphia. 